\title{
Orexin Receptor Antagonist
}

National Cancer Institute

\section{Source}

National Cancer Institute. Orexin Receptor Antagonist. NCI Thesaurus. Code C142786.

Any agent that inhibits the activity of the orexin receptor. 